\title{
EFEKTIVITAS APLIKASI SISTEM KEUANGAN DESA (STUDI TENTANG APLIKASI PELAPORAN KEUANGAN DESA DI DESA WAJAK LOR KECAMATAN BOYOLANGU KABUPATEN TULUNGAGUNG)
}

\section{EFFECTIVENESS OF VILLAGE FINANCIAL SYSTEM APPLICATIONS}

\author{
Muharsono $^{1}$, Linda Asyifah ${ }^{2}$ \\ ${ }^{1}$ Fakultas Ilmu Sosial dan Ilmu Politik Universitas Tulungagung, Tulungagung, Indonesia \\ ${ }^{2}$ Fakultas Ilmu Sosial dan Ilmu Politik Universitas Tulungagung, Tulungagung, Indonesia \\ muharsono212@gmail.com \\ lindaasyifah@gmail.com
}

\begin{abstract}
ABSTRAK
Latar belakang Penelitian tersebut ialah untuk mengantisipasi terjadinya masalah penyelewengan dana desa dan mendukung peraturan pengelolaan keuangan desa yang transparan, akuntabel, serta partisipatif, pemerintah bekerja sama dengan Kementerian Dalam Negeri dan BPKP untuk melakukan pengembangan aplikasi yang dinamakan Sistem Keuangan Desa (Siskeudes). Rumusan masalah dalam penelitian: 1) Bagaimana efektivitas aplikasi sistem keuangan desa di Desa Wajak Lor Kecamatan Boyolangu Kabupaten Tulungagung, 2) Apa saja kendala dalam penggunaan aplikasi sistem keuangan desa di Desa Wajak Lor Kecamatan Boyolangu Kabupaten Tulungagung. Penelitian ini menggunakan tipe penelitian deskriptif dengan pendekatan kualitatif. Pengumpulan data dilakukan dengan metode wawancara, observasi, dan dokumentasi. Subjek penelitian adalah Kepala Desa, Sekretaris Desa, Kaur Keuangan, Operator aplikasi sistem keuangan desa dan beberapa warga Desa Wajak Lor Kecamatan Boyolangu Kabupaten Tulungagung. Objek penelitiannya adalah aplikasi sistem keuangan desa. Pembuktian keabsahan data menggunakan teknik triangulasi sumber. Analisis data yang digunakan adalah analisi kualitatif dengan langkah reduksi data, penyajian data, penarikan kesimpulan dan verifikasi data. Hasil dari penelitian tersebut adalah : 1) Aplikasi sitem keuangan desa efektif diterapkan di Desa Wajak Lor Kecamatan Boyolangu Kabupaten Tulungagung sebagai aplikasi pelaporan keuangan desa. Hal ini dapat dilihat dari aplikasi ini mampu memberikan hasil yang maksimal. Laporan keuangan yang dihasilkan tertata rapi dan akurat. Pelaporan ke pusat semakin mudah. Selain itu tidak membutuhkan waktu yang lama untuk mengerjakannya. 2) Kendala yang dihadapi oleh pemerintah Desa Wajak Lor Kecamatan Boyolangu Kabupaten Tulungagung dalam penggunaan aplikasi sistem keuangan desa antara lain: Jika aplikasi sistem keuangan desa mengalami perubahan versi, maka operator segera belajar agar mampu menguasai perubahan pada aplikasi. Operator juga harus sigap dan teliti jika ada perubahan anggaran belanja yang muncul secara mendadak. Jika salah satu peralatan ada yang rusak dan harus dibawa ke servis, operator harus menunggu sampai peralatan tersebut selesai diperbaiki. Dan jika jaringan internet trobel maka operator juga harus menunggu sampai jaringan internet selesai diperbaiki. Sedangkan kendala yang berkaitan langsung dengan aplikasi sistem keuangan desa, yaitu adanya perubahan versi dari aplikasi sistem keuangan desa setiap setahun sekali, penggunaan dana yang bisa dilihat prosentasenya hanya yang bersumber dari Dana Desa (DD) yang lain tidak bisa, jika sudah lewat batas akhir pelaporan operator sudah tidak bisa
\end{abstract}




\section{PUBLICIANA : JURNAL ILMU SOSIAL DAN ILMU POLITIK \\ VOLUME 14, NO 02 \\ ISSN : 1979 - 0295 / E-ISSN : 2502 - 7336}

lagi mengentri data laporan karena sudah dikunci oleh server pusat, jika terdapat perubahan anggaran yang dituangkan di dalam Perkades (Peraturan Kepala Desa) kemudian perubahan tersebut dientri, operator tidak bisa lagi melihat anggaran-anggaran sebelumnya dan jika sudah masuk tahap pelaporan akhir server pusat sering error/down.

\section{Kata Kunci : Efektivitas, Aplikasi sistem keuangan desa, Aplikasi pelaporan keuangan desa.}

\section{ABSTRACT}

The background of the research is to anticipate the occurrence of misappropriation of village funds and to support transparent, accountable, and participatory village financial management regulations, the government collaborates with the Ministry of Home Affairs and BPKP to develop an application called the Village Financial System (Siskeudes). The formulation of the problem in the research: 1) How is the effectiveness of the village financial system application in Wajak Lor Village, Boyolangu District, Tulungagung Regency, 2) What are the obstacles in using the village financial system application in Wajak Lor Village, Boyolangu District, Tulungagung Regency. This study uses a descriptive type of research with a qualitative approach. Data was collected by interview, observation, and documentation methods. The research subjects were the Village Head, Village Secretary, Head of Finance, Operator of the village financial system application and several residents of Wajak Lor Village, Boyolangu District, Tulungagung Regency. The object of the research is the application of the village financial system. Proof of data validity using source triangulation technique. The data analysis used is qualitative analysis with data reduction steps, data presentation, conclusion drawing and data verification. The results of the research are: 1) The village financial system application is effectively implemented in Wajak Lor Village, Boyolangu District, Tulungagung Regency as a village financial reporting application. This can be seen from this application is able to provide maximum results. The resulting financial reports are neat and accurate. Reporting to the center just got easier. Besides that, it doesn't take long to do it. 2) Obstacles faced by the government of Wajak Lor Village, Boyolangu District, Tulungagung Regency in using the village financial system application include: If the village financial system application experiences a version change, the operator immediately learns to be able to master changes to the application. Operators must also be alert and careful if there is a sudden change in the budget. If any of the equipment is damaged and must be taken for service, the operator must wait until the equipment is repaired. And if the internet network is problematic, the operator must also wait until the internet network is repaired. While the obstacles that are directly related to the application of the village financial system, namely the change in the version of the village financial system application once a year, the use of funds that can be seen as a percentage only comes from the other Village Funds (DD), if it is past the reporting deadline the operator can no longer enter report data because it has been locked by the central server, if there is a budget change as outlined in the Perkades (Village Head Regulation) then the change is entered, the operator can no longer see previous budgets and if it has entered the final reporting stage central server often error / down.

Keywords: Effectiveness, Village Financial System Application, Village Financial

\section{PENDAHULUAN}

Desa merupakan struktur pemerintahan terkecil yang terdapat di kalangan masyarakat. Dalam Undang-Undang Nomor 6 Tahun 2014 disebutkan bahwa desa merupakan kesatuan 
masyarakat hukum yang memiliki batas wilayah berwenang untuk mengatur dan mengurus urusan pemerintah secara administratif, kepentingan masyarakat setempat berdasarkan prakarsa masyarakat, hak asal usul atau hak tradisional yang diakui dan dihormati dalam sistem pemerintahan Negara Kesatuan Republik Indonesia.

Undang-undang tentang Desa merupakan salah satu strategi dari perwujudan Nawacita ke-3 Pemerintahan Jokowi-JK, yaitu dengan membangun Indonesia dari pinggiran dan memperkuat daerah-daerah desa. Penerbitan undang-undang desa diharapkan memberikan peluang bagi aparatur pemerintah desa untuk mengelola segala tata pemerintahan serta mengurus pelaksanaan pembangunan untuk meningkatkan kesejahteraan masyarakat desa dengan berbagai kebijakan.

Kebijakan yang dilakukan untuk mendukung kemandirian desa adalah salah satunya dengan memberikan keleluasaan desa untuk mandapatkan pembiayaan langsung dari APBN tidak lain dalam rangka untuk mencari bentuk dan format ideal yang bisa menempatkan desa sebagai suatu daerah yang memiliki sifat istimewa dalam sistem ketatanegaraan Republik Indonesia. Pelaksanaan pembangunan desa harus didukung dengan jumlah anggaran yang dialokasikan. Tahun 2018 setiap desa mendapatkan rata-rata alokasi dana desa sebesar Rp 800.400.000,-, tahun 2019 sebesar Rp 933.900.000,-, dan tahun 2020 sebesar Rp 960.600.000,-. Dana Desa yang dialokasikan tahun 2020 sebesar Rp72 triliun diperuntukkan bagi 74.953 desa dan akan disalurkan oleh 169 Kantor Pelayanan Perbendaharaan Negara (KPPN). Alokasi dana desa tersebut kemudian akan dikelola oleh aparatur pemerintah desa sesuai APBDes yang didapatkan dan diawasi melalui sistem yang dikembangkan oleh Badan Pengawasan Keuangan dan Pembangunan (BPKP) (bpkp.go.id). Untuk mengantisipasi terjadinya masalah penyelewengan dana desa dan mendukung peraturan pengelolaan keuangan desa yang transparan, akuntabel, serta partisipatif, pemerintah bekerja sama dengan Kementerian Dalam Negeri dan BPKP untuk melakukan pengembangan aplikasi yang dinamakan Sistem Keuangan Desa (Siskeudes) (Gayatri \& Latrini, 2018).

Aplikasi Sistem Keuangan Desa (Siskeudes) merupakan kebijakan yang dibuat sesuai dengan Permendagri No. 20 Tahun 2018 tentang Pengelolaan Keuangan Desa, dimana kebijakan tersebut harus dijalankan agar tercapai tujuan dari aplikasi Siskeudes, yaitu agar pengelolaan keuangan desa bisa lebih bersih, tertib, efektif dan efisien serta terwujudnya pengelolaan keuangan desa yang transparan, akuntabel, partisipatif serta dilakukan dengan tertib dan disiplin anggaran. Sejak 2015, BPKP dan Kemendagri mendorong pengembangan kapasitas aparat desa dan pengelola keuangan desa berbasis Siskeudes melalui sosialisasi dan bimbingan teknis. Pada 27 November 2015, Kemendagri mengeluarkan SE Nomor 147/8350/BPD menginstruksikan agar Siskeudes diberikan cuma-cuma. Sosialisasi dan bimtek bagi aparatur pemerintahan desa dilakukan dengan pembiayaan APBD (kominfo.go.id).

Sebelum menggunakan aplikasi Siskeudes pemerintah desa dalam membuat laporan keuangan masih menggunakan cara manual dengan Microsoft Excel maupun Microsoft Word, cara manual ini dirasa masih kurang efektif dalam pembuatan laporan keuangan, namun sejak adanya aplikasi Siskeudes ini pemerintah merasa terbantu karena proses penggunaan aplikasi ini yang mudah dan lebih efektif dari pada menggunakan cara manual. Tetapi untuk menerapkan aplikasi Siskeudes ini aparat pemerintah memerlukan perangkat keras komputer dan koneksi internet untuk mendukung jalannya aplikasi ini.

Aplikasi Siskeudes di Kabupaten Tulungagung mulai diterapkan secara menyeluruh kepada desa-desa di Tulungagung yaitu pada tahun 2018. Sebelumnya, pada tahun 2017 pihak DPMD (Dinas Pemberdayaan Masyarakat dan Desa) Kabupaten Tulungagung memberikan pelatihan berupa pengenalan aplikasi dan bagaimana cara mengoperasikannya. Desa Wajak 


\section{PUBLICIANA : JURNAL ILMU SOSIAL DAN ILMU POLITIK \\ VOLUME 14, NO 02 \\ ISSN : 1979 - 0295 / E-ISSN : 2502 - 7336}

Lor merupakan salah satu desa di Kabupaten Tulungagung yang terletak di Kecamatan Boyolangu yang juga ikut menerapkan aplikasi Siskeudes secara aktif pada tahun 2018.

Pemerintah melalui BPKP menginginkan adanya pengelolaan keuangan desa yang akuntabel, partisipatif, transparan dan tertib artinya dalam mengelola keuangan desa tidak ada yang disembunyikan oleh pemerintah desa kepada masyarakat dalam memberikan data benar sesuai dengan pelaksanaan anggaran yang real di lapangan, tetapi hal itu tidaklah demikian karena pada kenyataannya sebelum ada aplikasi Siskeudes masyarakat masih sulit mencari informasi yang benar tentang pengelolaan keuangan desa. Aplikasi ini juga tergolong masih baru sumber daya atau kapasitas teknis juga masih belum benar- benar menguasai aplikasi Siskeudes ini sehingga aplikasi Siskeudes dirasa belum sepenuhnya efektif.

\section{KERANGKA TEORI}

\section{A. Pengertian Efektivitas}

Efektivitas merupakan unsur pokok untuk mencapai tujuan atau sasaran yang telah ditentukan di dalam setiap organisasi, kegiatan ataupun program. Efektivitas juga merupakan suatu tingkat keberhasilan yang dihasilkan oleh seseorang atau organisasi dengan cara tertentu sesuai dengan tujuan yang hendak dicapai. Pengertian efektivitas menurut (Bungkaes et al., 2013) adalah penilaian yang dibuat sehubungan dengan prestasi individu, kelompok dan organisasi. Semakin dekat prestasi mereka terhadap prestasi yang diharapkan "standar" maka mereka dinilai semakin efektif.

\section{B. Indikator Efektivitas}

Mengukur efektivitas bukanlah suatu hal yang sangat sederhana, karena efektivitas dapat dikaji dari berbagai sudut pandang dan tergantung pada siapa yang menilai serta menginterpretasikannya. Tingkat efektivitas juga dapat diukur dengan membandingkan antara rencana yang telah ditentukan dengan hasil nyata yang telah diwujudkan. Namun, jika usaha atau hasil pekerjaan dan tindakan yang dilakukan tidak tepat sehingga menyebabkan tujuan tidak tercapai atau sasaran yang diharapkan, maka hal itu dikatakan tidak efektif. Sedangkan menurut (Campbell, 1989) dalam (Firdaus, 2009) bahwa terdapat cara pengukuran efektivitas secara umum dan yang paling menonjol adalah sebagi berikut:

1. Keberhasilan program

Efektivitas program dapat dijalankan dengan kemampuan operasional dalam melaksanakan program-program kerja yang sesuai dengan tujuan yang telah ditetapkan sebelumnya. Keberhasilan program dapat ditinjau dari proses dan mekanisme suatu kegiatan yang dilakukan di lapangan.

2. Keberhasilan sasaran

Efektivitas ditinjau dari sudut pencapaian tujuan dengan memusatkan perhatian terhadap aspek output, artinya efektivitas dapat diukur dengan seberapa jauh tingkat output dalam kebijakan dan prosedur dari organisasi untuk mencapai tujuan yang telah ditetapkan.

3. Kepuasan terhadap program

Kepuasan merupakan kriteria efektivitas yang mengacu pada keberhasilan program dalam memenuhi kebutuhan pengguna. Kepuasan dirasakan oleh para pengguna terhadap kualitas produk atau jasa yang dihasilkan. Semakin berkualitas produk dan jasa yang diberikan maka kepuasan yang dirasakan oleh pengguna semakin tinggi, maka dapat menimbulkan keuntungan bagi lembaga.

4. Tingkat input dan output 
Pada efektivitas tingkat input dan output dapat dilihat dari perbandingan antara masukan (input) dengan keluaran (output). Jika output lebih besar dari input maka dapat dikatakan efisien dan sebaliknya jika input lebih besar dari output maka dapat dikatakan tidak efisien.

5. Pencapaian tujuan menyeluruh

Sejauhmana organisasi melaksanakan tugasnya untuk mencapai tujuan. Dalam hal ini merupakan penilaian umum dengan sebanyak mungkin kriteria tunggal dan menghasilkan penilaian umum efektivitas organisasi.

\section{A. Pengertian Desa}

Pengertian desa menurut UU. No. 6 Tahun 2014 adalah desa dan desa adat atau yang disebut dengan nama lain, selanjutnya disebut desa, adalah masyarakat hukum yang memiliki batas wilayah yang berwenang untuk mengatur dan mengurus urusan pemerintahan, kepentingan masyarakat setempat berdasarkan prakarsa masyarakat, hak asal usul, dan atau hak tradisional yang diakui dan dihormati dalam sistem pemerintahan Negara Kesatuan Republik Indonesia.

Sedangkan pengertian desa menurut UU. No. 32 Tahun 2004 adalah kesatuan masyarakat hukum yang memiliki batas-batas wilayah tertentu, berwenang untuk mengatur dan mengurus tugas kepentingan masyarakat setempat berdasarkan asal-usul dan adat istiadat setempat yang diakui dan/atau dibentuk dalam sistem pemerintahan Nasional dan berada di kabupaten/kota. Sehingga dapat disimpulkan bahwa desa adalah suatu kesatuan komunitas kecil yang menetap di suatu wilayah tertentu berdasarkan adat dan hukum adat yang sama, mereka berhak menyelenggarakan rumah tangganya sendiri dan mayoritas pekerjaannya di sektor pertanian, peternakan dan usaha lainnya.

\section{B. Keuangan Desa}

Menurut Undang-undang Nomor 6 Tahun 2014 yang tertuang dalam Pasal 1 Keuangan desa adalah segala hak dan kewajiban yang dapat diukur dan bernilai berupa uang atau barang. Hak dan kewajiban tersebut menimbulkan pendapatan, belanja, pembiayaan serta pengelolaan keuangan desa. Keuangan desa diperoleh dari Pendapatan Asli Desa (PADesa). Anggaran Pendapatan dan Belanja Daerah (APBD), dan Anggaran Pendapatan dan Belanja Negara (APBN) yang didanai oleh pemerintah pusat maupun pemerintah daerah.

Dalam Permendagri Nomor 113 Tahun 2014 mengenai asas pengelolaan keuangan desa menjelaskan keuangan desa harus dikelola berdasarkan asas-asas transparan, akuntabel, partisipatif, dilakukan dengan tertib dan disiplin anggaran. Pengelolaan keuangan desa dikelola dalam masa 1 periode akuntansi atau setara dengan 1 (satu) tahun anggaran. Keuangan desa merupakan asset yang harus dikelola dengan baik oleh seorang Kepala Desa yang melibatkan peran serta masyarakat dalam setiap kegiatan dan pengambilan keputusan sehingga tujuan dari progam pemerintah untuk lebih memfokuskan kesejahteraan masyarakat desa melalui penyaluran dana desa yang dikhususkan untuk operasional desa dapat tercapai.

Berdasarkan pengertian tersebut dapat disimpulkan bahwa keuangan desa adalah segala sesuatu yang berhubungan dengan uang dan barang yang digunakan untuk melaksanakan hak dan kewajiban desa.

\section{Pengelolaan Keuangan Desa}

Pengelolaan Keuangan adalah perencanaan, pengarahan, pemantauan, pengorganisasian, dan pengendalian sumber daya moneter dari sebuah organisasi yang efisien dan efektif untuk mencapai tujuan organisasi. Pengelolaan Keuangan Desa adalah keseluruhan kegiatan yang meliputi perencanaan, pelaksanaan, penatausahaan, pelaporan, dan pertanggung- jawaban keuangan desa. Pengawasan dan pemeriksaan terhadap pengelolaan keuangan desa yang terkandung Peraturan Menteri Dalam Negeri Nomor 37 Tahun 2007 


\section{PUBLICIANA : JURNAL ILMU SOSIAL DAN ILMU POLITIK \\ VOLUME 14, NO 02 \\ ISSN : 1979 - 0295 / E-ISSN : 2502 - 7336}

secara jelas dilakukan oleh masyarakat maupun lembaga yang berada dan diakui oleh desa yakni Badan Permusyawaratan Desa (BPD), namun pada ketentuan tersebut tidak disinggung secara langsung mengenai lembaga audit apa yang akan melakukan pemeriksaan keuangan desa. Kondisi demikian, menjadikan pertanyaan mendasar disini adalah apakah keuangan desa merupakan bagian dari sistem keuangan Negara atau daerah.

Kepala Desa adalah pemegang kekuasaan pengelolaan keuangan desa. Dalam melaksanakan kekuasaan sebagaimana dimaksud, Kepala Desa menguasakan sebagian kekuasaannya kepada perangkat desa. Berdasarkan pengertian tersebut dapat disimpulkan bahwa pengelolaan keuangan desa adalah keseluruhan kegiatan dimana kepala desa memiliki kekuasaan penuh untuk mengelola keuangan desa.

\section{Aplikasi Sistem Keuangan Desa}

Menurut (Jogiyanto, 2017) aplikasi merupakan penerapan, menyimpan sesuatu hal, data, permasalahan, pekerjaan kedalam suatu sarana atau media yang dapat digunakan untuk menerapkan atau mengimplementasikan hal atau permasalahan yang ada sehingga berubah menjadi suatu bentuk yang baru tanpa menghilangkan nilai-nilai dasar dari hal data, permasalahan, dan pekerjaan itu sendiri. Sedangkan menurut (Sanjaya, 2015) dalam Dhanta aplikasi adalah software yang dibuat oleh suatu perusahaan komputer untuk mengerjakan tugas-tugas tertentu, misalnya Microsoft Word, Microsoft Excel dan lainnya.

\section{METODE PENELITIAN}

Penelitian ini menggunakan tipe penelitian deskriptif dengan pendekatan kualitatif. Pendekatan kualitatif adalah metode penelitian yang berlandaskan filsafat postpositivisme, untuk meneliti kondisi obyek yang alamiah (Sugiyono, 2015). Data yang dikumpulkan berupa data hasil wawancara, catatan lapangan, dokumen pribadi, dan dokumen resmi lainnya.

Pendekatan penelitian kualitatif bertujuan untuk menggambarkan dan memberikan pemahaman bagaimana efektivitas aplikasi sistem keuangan desa di Desa Wajak Lor Kecamatan Boyolangu Kabupaten Tulungagung serta kendala-kendala yang terkait. Penelitian ini difokuskan pada:

1. Efektivitas aplikasi sistem keuangan desa di Desa Wajak Lor Kecamatan Boyolangu Kabupaten Tulungagung. Dengan indikator sebagai berikut:
a) Keberhasilan Program
b) Keberhasilan Sasaran
c) Kepuasan Terhadap Program
d) Tingkat Input dan Output
e) Pencapaian Tujuan Menyeluruh

2. Kendala-kendala yang dihadapi dalam pelaksanaan penggunaan aplikasi sistem keuangan desa di Desa Wajak Lor Kecamatan Boyolangu Kabupaten Tulungagung. Dengan indikator sebagai berikut:
a) SDM (Sumber Daya Manusia)
b) Sarana dan Prasarana
c) Aplikasi Sistem Keuangan Desa

Lokasi penelitian merupakan tempat yang akan dijadikan dalam proses pengambilan data (Herdiansyah, 2012). Lokasi penelitian ini dilakukan di Kantor Desa Wajak Lor Kecamatan Boyolangu Kabupaten Tulungagung. Teknik analisis data dalam penelitian ini menggunakan model interaktif yang dikemukakan oleh Miles dan Huberman. Terdiri dari beberapa langkah yaitu, reduksi data, penyajian data, penarikan kesimpulan dan verifikasi data. 


\section{HASIL DAN PEMBAHASAN}

\section{A. PEMBAHASAN}

\section{Efektivitas Aplikasi Sistem Keuangan Desa di Desa Wajak Lor Boyolangu Kabupaten Tulungagung}

Kecamatan

Untuk mengetahui efektivitas aplikasi sistem keuangan desa ini peneliti mengukurnya dengan beberapa indikator yang telah dikemukakan oleh Campbell J.P. antara lain sebagai berikut:

a) Keberhasilan Program

Sebelum menggunakan aplikasi sistem keungan desa, pemerintah Desa Wajak Lor menggunakan cara manual dalam membuat rencana anggaran maupun laporan keuangan desa yaitu dengan menggunakan Microsoft Word dan Microsoft Excel. Cara ini tentunya memerlukan banyak waktu untuk menyelesaikannya. Pada tahun 2018 Desa Wajak Lor mendapatkan mandat untuk menggunakan aplikasi sistem keuangan desa sebagai aplikasi pelaporan keuangan desa. Seiring perkembangan teknologi, cara manual dirasa sudah tidak efektif memenuhi tuntutan pekerjaan. Semua serba terkomputerisasi dan online. Setelah melalui penyempurnaan beberapa versi, saat ini pemerintah Desa Wajak Lor Kecamatan Boyolangu Kabupaten Tulungagung menggunakan aplikasi sistem keuangan desa versi V2.0.R2.0.2. Dalam aplikasi sistem keuangan desa sudah mencakup semua hal yang berkaitan dengan keuangan desa mulai dari penganggaran biaya, pentransferan uang, pengambilan uang, penggunaan dana dan laporan keuangan desa. Misalnya laporan realisasi penggunaan dana APBDes, Laporan Realisasi Belanja, PMK 225 dan sebagainya. Aplikasi ini sangat efektif untuk digunakan, selain pengerjaannnya tidak membutuhkan waktu terlalu lama hasilnya bisa maksimal. Laporan keuangannya juga tertata rapi dan akurat. Pelaporan ke pusat juga semakin mudah.

b) Keberhasilan Sasaran

Sasaran dari pada program atau aplikasi sistem keuangan desa ini adalah tata kelola keuangan desa. Dengan aplikasi sistem keuangan desa ini mampu meningkatkan tata kelola keuangan desa di Desa Wajak Lor Kecamatan Boyolangu Kabupaten Tulungagung. Pengelolaan keuangan di desa menjadi lebih mudah. Pos-pos untuk anggaran yang semula masih rancu, sekarang lebih terperinci. Laporan keuangan yang dihasilkan dari aplikasi sistem keuangan desa ini juga akurat. Aplikasi ini juga efektif meningkatkan kinerja pemerintah Desa Wajak Lor, hal ini dapat dilihat dari banyaknya kemajuan dalam pengelolaan keuangan desa dibanding sebelum menggunakan aplikasi sistem keuangan desa.

c) Kepuasan Terhadap Program

Pihak pemerintah Desa Wajak Lor yang merasa puas dan terbantu dengan dengan program atau aplikasi sistem keuangan desa ini, karena memberikan dampak yang efektif dan hasil yang maksimal untuk pekerjaan yang berkaitan dengan keuangan desa. Selain dari pihak pemerintah desa, warga masyarakat Desa Wajak Lor juga merasa puas. Dulu masyarakat merasa kebingungan jika ingin mengetahui bagaimana keadaan keuangan desa. Sekarang pihak pemerintah desa menjadi lebih terbuka. Selain mengadakan Musrenbangdes, keadaan keuangan desa bisa dilihat di papan pengumuman di Kantor Desa maupun di baliho yang dipasang di sekitar Kantor Desa.

d) Tingkat Input dan Output

Data yang sudah diinput ke dalam aplikasi sistem keuangan desa yaitu berupa data perencanaan, penganggaran, penataausahaan dan pembukuan yang disusun berdasarkan RPJMDesa, RKPDesa dan Musrenbangdes. Semua itu berisi data kegiatan pelaksanaan program-program yang akan atau telah direalisasikan oleh pemerintah Desa Wajak Lor 


\section{PUBLICIANA : JURNAL ILMU SOSIAL DAN ILMU POLITIK \\ VOLUME 14, NO 02 \\ ISSN : 1979 - 0295 / E-ISSN : 2502 - 7336}

Kecamatan Boyolangu Kabupaten Tulungagung selama satu tahun, yang kemudian akan menjadi output yaitu hasil dari capaian kerja dari program-program tersebut nantinya akan dibuat laporan-laporan terkait program yang telah dijalankan selama satu tahun penuh dan laporan-laporan tersebut dibuat dengan aplikasi sistem keuangan desa. Untuk proses input data pada aplikasi sistem keuangan desa ini tergolong mudah. Di dalam aplikasi ini sudah tersedia pos-pos untuk anggaran yang sudah terperinci, jadi operator tinggal memilih pos mana yang sesuai kemudian dimasukkan nominalnya. Pelaporan keuangan yang biasanya membutuhkan waktu 3-4 minggu kini dapat diselesaikan dalam waktu 1 minggu. Sehingga pekerjaan lebih efektif dan efisien hasilnya juga maksimal.

e) Pencapaian Tujuan Menyeluruh

Pemerintah melalui BPKP menginginkan adanya pengelolaan keuangan desa yang akuntabel, partisipatif, transparan dan tertib. Maka dari itu pemerintah desa berupaya penuh agar aplikasi sistem keuangan desa ini bisa beroperasi secara optimal. Selain sarana dan prasarana yang memadai, pemerintah desa juga membekali diri khususnya operator sistem keuangan desa dengan mengikuti pelatihan atau penyuluhan yang terkait dengan aplikasi ini. Melalui aplikasi sistem keuangan desa ini pemerintah desa bisa menata dan mengelola keuangan desa secara rinci, tepat dan akurat. Pelaporan keuangan kepada pusat juga dapat dilakukan dengan tertib.

Tercapainya tujuan dari pada program atau aplikasi sistem keuangan desa dapat dilihat dari:

1. Akuntabel

Laporan keuangan yang dihasilkan dari aplikasi sistem keuangan desa ini sudah memenuhi Standar Akuntansi Pemerintahan (SAP) yaitu relevan, andal, dapat dibandingkan dan dapat dipahami.

2. Partisipatif

Dalam aplikasi sistem keuangan desa ini masyarakat juga dilibatkan dalam perencanaan pembangunan. Usulan perencanaan pembangunan dari masyarakat ditampung dan dimusyawarahkan antara pihak desa dan perwakilan warga. Usulan perencanaan yang sudah disetujui bersama ini nanti dimasukkan pada sistem dalam bentuk RAB (Rencana Anggaran Biaya) yang direalisasikan untuk tahun berikutnya.

\section{Transparan}

Setiap awal tahun pihak desa mengadakan musyawarah dengan perwakilan warga. Pihak pemerintah desa juga menempelkan sejumlah laporan keuangan di papan pengumuman yang ada di Kantor Desa Wajak Lor. Selain itu juga mencetak informasi keuangan desa dalam bentuk baliho yang dipasang di dekat Kantor Desa. Baliho ini didalamnya berisi grafik-grafik dan angka-angka tentang keuangan desa yang mudah dibaca dan dipahami oleh masyarakat.

\section{Kendala-Kendala dalam Penggunaan Aplikasi Sistem Keuangan Desa di Desa Wajak Lor Kecamatan Boyolangu Kabupaten Tulungagung}

Setiap aplikasi pasti ada kelebihan dan kekurangannya. Begitupun sama dengan aplikasi sistem keuangan desa ini. Pihak pemerintah Desa Wajak Lor merasa terbantu dan merasa puas dengan adanya aplikasi ini. Setiap akhir tahun bisa melakukan pelaporan realisasi dengan cermat dan tepat. Pelaporan ke pihak pusat juga lebih mudah.

Bebarapa kendala yang dihadapi oleh pemerintah Desa Wajak Lor Kecamatan Boyolangu Kabupaten Tulungagung dalam mengoperasikan aplikasi sistem keuangan desa antara lain:

a) Sumber Daya Manusia (SDM) 
Sumber Daya Manusia (SDM) di sini adalah operator sistem keuangan desa yang berkaitan langsung dengan pengoperasian aplikasi sistem keuangan desa. Kendala yang dihadapi operator dalam mengoperasikan aplikasi sistem keuangan desa adalah jika aplikasi ini mengalami perubahan versi, maka operator segera belajar agar mampu menguasai aplikasi ini sehingga operator bisa dengan cepat menyesuaikan dan memahami kembali perubahan tersebut.

Selain itu operator juga sigap dan teliti jika ada perubahan anggaran belanja yang muncul secara mendadak, misalnya anggaran untuk penanganan musibah. Setiap perubahan anggaran dikerjakan secara cermat dan hati-hati, karena perubahan ini akan berdampak ke rencana anggaran biaya yang lain.

b) Sarana dan Prasarana

Untuk menunjang pengoperasian aplikasi sistem keuangan desa, Pihak pemerintah Desa Wajak Lor melengkapi aplikasi ini dengan satu buah unit Laptop dengan spesifikasi yang bagus, satu buah unit printer dan jaringan internet (WIFI).

Kendalanya jika salah satu peralatan ada yang rusak dan harus dibawa ke servis, operator harus menunggu sampai peralatan tersebut selesai diperbaiki. Dan jika jaringan internet trobel maka operator juga harus menunggu sampai jaringan internet selesai diperbaiki. Kalau servis memakan waktu yang lama operator harus berusaha mencari alternatif lain. Bisa memakai laptop pribadi atau mencari pinjaman laptop. Untuk jaringan internet bisa disiasati dengan menyambungkan jaringan internet laptop menggunakan paket data internet yang ada di handphone (HP).

c) Aplikasi Sistem Keuangan Desa

Beberapa kendala yang berkaitan langsung dengan aplikasi sistem keuangan desa, yaitu:

1. Adanya perubahan versi dari aplikasi sistem keuangan desa setiap setahun sekali sehingga perlu pengenalan dan pelatihan ulang, serta perlu mempelajari kembali dari perubahan versi tersebut.

2. Penggunaan dana yang bisa dilihat prosentasenya hanya yang bersumber dari Dana Desa (DD) yang lain seperti Pendapatan Asli Desa (PAD), Alokasi Dana Desa (ADD) yang bersumber dari APBD, Bagi Hasil Pajak/Retribusi (BHP) dan Bantuan Keuangan tidak bisa.

3. Jika sudah lewat batas akhir pelaporan, operator sudah tidak bisa lagi mengentri data laporan karena sudah dikunci oleh server pusat, jadi harus tertib waktu.

4. Jika terdapat perubahan anggaran yang dituangkan di dalam Perkades (Peraturan Kepala Desa) kemudian perubahan tersebut dientri, operator tidak bisa lagi melihat anggaran-anggaran sebelumnya. Dan anggaran tersebut tidak bisa langsung dialokasikan ke pos yang lain. Harus menunggu bulan perubahan untuk merubah anggaran tersebut.

5. Jika sudah masuk tahap pelaporan akhir server pusat sering error/down. Dimungkinkan karena banyaknya operator desa yang mengakses untuk pelaporan.

\section{KESIMPULAN DAN SARAN}

\section{A. Kesimpulan}

Berdasarkan hasil penelitan dan pembahasan yang peneliti lakukan tentang Efektivitas Aplikasi Sistem Keuangan Desa di Desa Wajak Lor Kecamatan Boyolangu Kabupaten Tulungagung, maka dapat disimpulkan sebegai berikut:

Aplikasi sitem keuangan desa efektif diterapkan di Desa Wajak Lor Kecamatan Boyolangu Kabupaten Tulungagung sebagai aplikasi pelaporan keuangan desa dibandingkan dengan menggunakan cara manual. Hal ini dapat dilihat dari aplikasi ini mampu memberikan hasil yang maksimal. Laporan keuangan yang dihasilkan tertata rapi dan akurat. Pelaporan ke 


\section{PUBLICIANA : JURNAL ILMU SOSIAL DAN ILMU POLITIK \\ VOLUME 14, NO 02 \\ ISSN : 1979 - 0295 / E-ISSN : 2502 - 7336}

pusat semakin mudah. Selain itu tidak membutuhkan waktu yang lama untuk mengerjakannya.

Dalam aplikasi sistem keuangan desa sudah mencakup semua hal yang berkaitan dengan keuangan desa mulai dari penganggaran biaya, pentransferan uang, pengambilan uang, penggunaan dana dan laporan keuangan desa. Misalnya laporan realisasi penggunaan dana APBDes, Laporan Realisasi Belanja, PMK 225 dan sebagainya.

Aplikasi sistem keuangan desa mampu meningkatkan tata kelola keuangan desa di Desa Wajak Lor Kecamatan Boyolangu Kabupaten Tulungagung. Pengelolaan keuangan di desa menjadi lebih mudah dan terperinci. Aplikasi ini juga mampu meningkatkan kinerja aparat pemerintah Desa. Selain itu. Pemerintah desa juga lebih transparan kepada warga masyarakat terkait informasi rencana pembangunan dan anggaran dana desa.

Kendala yang dihadapi oleh pemerintah Desa Wajak Lor Kecamatan Boyolangu Kabupaten Tulungagung dalam penggunaan aplikasi sistem keuangan desa antara lain:

a. Jika aplikasi sistem keuangan desa mengalami perubahan versi, maka operator segera belajar agar mampu menguasai perubahan pada aplikasi. Operator juga harus sigap dan teliti jika ada perubahan anggaran belanja yang muncul secara mendadak.

b. Jika salah satu peralatan ada yang rusak dan harus dibawa ke servis, operator harus menunggu sampai peralatan tersebut selesai diperbaiki. Dan jika jaringan internet trobel maka operator juga harus menunggu sampai jaringan internet selesai diperbaiki.

c. Kendala yang berkaitan langsung dengan aplikasi sistem keuangan desa, yaitu adanya perubahan versi dari aplikasi sistem keuangan desa setiap setahun sekali, penggunaan dana yang bisa dilihat prosentasenya hanya yang bersumber dari Dana Desa (DD) yang lain tidak bisa, jika sudah lewat batas akhir pelaporan operator sudah tidak bisa lagi mengentri data laporan karena sudah dikunci oleh server pusat, jika terdapat perubahan anggaran yang dituangkan di dalam Perkades (Peraturan Kepala Desa) kemudian perubahan tersebut dientri, operator tidak bisa lagi melihat anggarananggaran sebelumnya dan jika sudah masuk tahap pelaporan akhir server pusat sering error/down.

\section{B. Saran}

Berdasarkan kesimpulan di atas maka dapat disampaikan beberapa saran bagi pemerintah Desa Wajak Lor Kecamatan Boyolangu Kabupaten Tulungagung, sebagai berikut:

Pemerintah Desa Wajak Lor Kecamatan Boyolangu Kabupaten Tulungagung lebih meningkatkan daya guna aplikasi sistem keuangan desa yang telah diterapkan.

Meningkatkan sinergitas antar perangkat desa dan laporan keuangan desa bisa diupload di website desa agar dapat dijangkau oleh masyarakat lebih luas lagi, yang mana tujuannya agar masyarakat sendiri dapat lebih percaya terhadap pemerintah Desa Wajak Lor Kecamatan Boyolangu KabupatenTulungagung.

Terkait kendala yang dihadapi oleh Pemerintah Desa Wajak Lor Kecamatan Boyolangu Kabupaten Tulungagung dalam penggunaan aplikasi sistem keuangan desa, peneliti memberikan beberapa solusi yaitu: Jika aplikasi sistem keuangan desa telah mengalami perubahan versi, maka pemerintah Desa Wajak Lor khususnya operator aplikasi sistem keuangan desa harus mempersiapkan diri dan sigap dalam menghadapinya. Cepat belajar untuk menyesuaikan diri agar benar-benar mampu menguasai dan memahami kembali perubahan tersebut. Agar pelaporan tidak mundur dari jadwal, pemerintah Desa Wajak Lor harus selalu berusaha tertib dan tepat waktu dalam mengentri data untuk pelaporan. 


\section{DAFTAR PUSTAKA}

Bungkaes, H. R., Posumah, J. H., \& Kiyai, B. (2013). Hubungan efektivitas pengelolaan program raskin dengan peningkatan kesejahteraan masyarakat di Desa Mamahan Kecamatan Gemeh Kabupaten Kepualauan Talaud. ACTA DIURNA KOMUNIKASI, 2(2).

Campbell, J. P. (1989). Dietary treatment of infant colic: a double-blind study. The Journal of the Royal College of General Practitioners, 39(318), 11-14.

Firdaus, K. (2009). Efektivitas Layanan Mobile Application "mLibrary" di Perpustakaan Universitas Gajah Mada. Jurnal Penelitian.

Gayatri, G., \& Latrini, M. Y. (2018). Efektivitas Penerapan Sistem Keuangan Desa dan Kualitas Laporan Keuangan Desa. Jurnal Ilmiah Akuntansi Dan Bisnis, 13(2), 113-122.

Jogiyanto, H. M. (2017). Analisis dan Desain (Sistem Informasi Pendekatan Terstruktur Teori dan Praktek Aplikasi Bisnis). Penerbit Andi.

Sanjaya, W. (2015). Perencanaan dan desain sistem pembelajaran. Kencana. 